\title{
Performance of Shariah and Non Shariah Compliance F\&B Firms in Malaysia: Is there any Difference?
}

Salwani Affandi, Nur Izzatie Zainuddin and Fadli Fizari Abu Hassan Asari

To Link this Article: http://dx.doi.org/10.6007/IJARBSS/v11-i18/11419

DOI:10.6007/IJARBSS/v11-i18/11419

Received: 04 August 2021, Revised: 24 August 2021, Accepted: 15 September 2021

Published Online: 02 October 2021

In-Text Citation: (Affandi et al., 2021)

To Cite this Article: Affandi, S., Zainuddin, N. I., \& Asari, F. F. A. H. (2021). Performance of Shariah and Non Shariah Compliance F\&B Firms in Malaysia: Is there any Difference? International Journal of Academic Research in Business and Social Sciences, 11(18), 1-11.

Copyright: (C) 2021 The Author(s)

Published by Human Resource Management Academic Research Society (www.hrmars.com)

This article is published under the Creative Commons Attribution (CC BY 4.0) license. Anyone may reproduce, distribute, translate and create derivative works of this article (for both commercial and non-commercial purposes), subject to full attribution to the original publication and authors. The full terms of this license may be seen at: http://creativecommons.org/licences/by/4.0/legalcode

Special Issue Title: TiBECVII 2021, 2021, Pg. 1 - 11

Full Terms \& Conditions of access and use can be found at http://hrmars.com/index.php/pages/detail/publication-ethics 


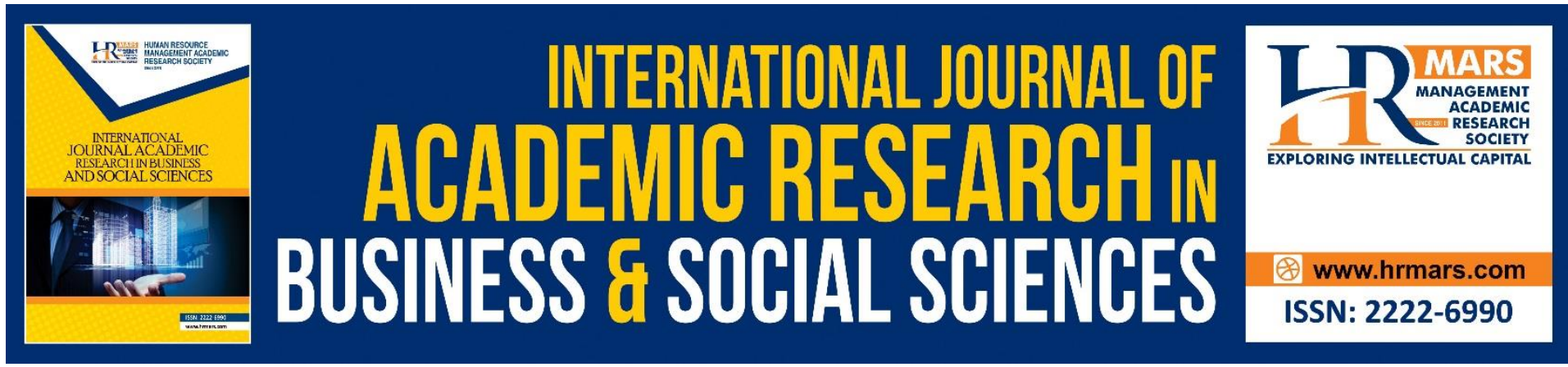

\title{
Performance of Shariah and Non Shariah Compliance F\&B Firms in Malaysia: Is there any Difference?
}

\author{
${ }^{1}$ Salwani Affandi, ${ }^{3}$ Nur Izzatie Zainuddin and ${ }^{2}$ Fadli Fizari Abu \\ Hassan Asari \\ ${ }^{1}$ Faculty of Business and Management, Universiti Teknologi MARA Cawangan Terengganu, \\ Malaysia, ${ }^{2}$ Faculty of Business and Management, Universiti Teknologi, MARA Cawangan \\ Perlis, Malaysia, ${ }^{3}$ Klesjaya Sdn Bhd., Kuala Lumpur \\ Email: salwaniaffandi@uitm.edu.my
}

\begin{abstract}
Foods and beverages are a sub-sector of the consumer and product services industry, with the biggest consumer demand among the industries listed on the Bursa Malaysia. The significant performance factors of Shariah Compliance and Non-Shariah Compliance companies in Malaysia's food and beverage sector were uncovered in this study. The study spans the years 2008 to 2017, with 350 observations from Shariah-compliant and noncompliant firms. Utilizing the Random Effect Model (REM), the data show that for Shariah Compliance enterprises, quick ratio and total asset have a positive link with return on asset, however for Non-Compliance enterprises, only total asset has a positive association with profitability and the others are adversely related. Except for total assets, the results of random effect model regression demonstrated that all independent factors, including quick ratio, debt ratio, tax rate, and tangibility, have a substantial impact on the ROA of Shariah compliance enterprises. Nonetheless, there are three independent variables that are significant for Non Shariah Compliance in terms of return on asset: debt ratio, tax rate, and tangibility. The profitability of non-Shariah compliant enterprises is unaffected by log assets or the quick ratio.
\end{abstract}

Keywords: Performance, Shariah Compliance Firms, Non-Shariah Compliance Firms, Random Effect Model, Return on Assets

\section{Introduction}

Profitability can be described as an ability of a company to earn a profit. It can be measured in a various way not only by return on asset (ROA), but it can be return on equity (ROE) or net profit margin (NPM). When it comes to firm performance, most researchers will associate it with profitability, with the higher the profitability, the better and steadier the performance. The focus of this research was on food and beverage (F\&B) companies that were publicly traded on the Malaysian stock exchange, Bursa Malaysia. Companies listed on Bursa Malaysia are divided into two categories: Shariah Compliance and Non-Shariah Compliance. As a result, in terms of how enterprises produce or market their products to consumers, the performance 
of Shariah Compliance and Non-Shariah Compliance may be contradictory. Shahar (2015) discovered that debt ratio has no impact on Shariah compliant company performance based on return on asset (ROA) and return on equity (ROE), but short-term and long-term debt have a negative impact on Shariah compliant company performance based on market to book value (MTBV).

Furthermore, these categories constitute a crucial issue for investors when deciding whether or not to invest in companies that follow Shariah Compliance or traditional business practises. This is due to their fear over their earnings. According to McGowan \& Muhammad, (2010), some scholars have also explained that the performance divergence between two stock categories should be modest. Some argue that conventional equities should do better than Islamic ones. As a result, investors who are concerned about their wealth, investments, and profits being Shariah compliant would sell non-Shariah compliance equities and replace them with Shariah compliant equities. As a result, the stock price will be affected. Despite this, stocks that were previously non-Shariah compliant but have now been identified as Shariah Compliant are expected to rise in value (Lusyana et al., 2017). Despite the fact that food and beverage performance has improved dramatically from year to year, there is a dearth of evidence from past study focusing on the performance of F\&B Shariah and non-Shariah compliance organisations. As a result, the purpose of this research is to determine the performance of both types of businesses.

Despite the enormous number of academic research on performance, the evidence on the relationship between profitability and firm-specific characteristics when comparing Shariah Compliant and non-Shariah Compliant enterprises is currently insufficient and confusing. As a result, the researchers are driven to investigate the relationship between profitability as measured by the ROA and the firm's specific variables. Next, though many research has been conducted on profitability, only a small number of research have included and concentrated on the comparison of performance between Shariah Compliant and Non Shariah Compliant enterprises. Many other studies, such as Taslim (2017); Ahmad (2017); Eitokpa (2015), have looked at the factors of food and beverage firm profitability in a variety of nations across time, but none of them have compared the performance of Shariah Compliant and Non Shariah Compliant enterprises. As a result, the purpose of this study is to emphasise the performance differences between the two types of food and beverage companies listed on Bursa Malaysia.

\section{Literature Review}

According to H-Sufi (2012), firm success is measured by return on assets (ROA). This viewpoint is consistent with Tailab (2014), who discovered that short-term debt (STD) has no significant beneficial influence on return on equity (ROE), whereas long-term debt (LTD) has a positive and significant influence on profitability. Profitability is measured by return on assets (ROA), return on equity (ROE), and net interest income (NIM), according to (Sathyamoorthi et al., 2017). This is similar to Cheng and Huang (2015), who found that profitability is measured by return on assets (ROA), return on equity (ROE), and net interest income (NIM). Only when using ROA as a measure of profitability they discovered that better capitalised banks are more profitable. Furthermore, return on assets (ROA), return on sales (ROS), and economic value added (EVA) were used by Mokhtar (2006) to evaluate corporate performance (EVA). They discovered that all three variables appear to be associated with ISO 9000 registration in a substantial positive way. When it comes to the relationship between capital structure and 
performance indicators, ROA and ROS exhibit strong negative correlations with capital structure.

According to Dioha et al (2018), the quick ratio has a negative association with the firm's performance, which is defined as return on assets (ROA). Similarly, according to Phan (2013), there is a negative relationship between liquidity and company performance (ROA). Because of the large debt in a corporation, the outcome of reducing current assets and increasing current liabilities will result in a reduction in the quick ratio. Ismail and Subramaniam (2017), on the other hand, discovered a favourable relationship between liquidity and consumer goods firm performance. This is similar to Umi and Noraina (2017), who found a positive connection between quick ratios and performance. They further said that every firm should maintain an appropriate level of working capital, and that if it doesn't seem to, it will have an impact on the company's probability. As a result, it's believed that the liquidity relationship is associated to maintaining a healthy level of working capital.

Likewise, Bhutta and Hasan (2013) discovered a negative link between debt ratio and return on assets. They argued that the more debt a company has in relation to its overall assets, the more heavily leveraged it is. This study is consistent with Dogan (2013), who reported a negative association between leverage and company performance, implying that rising leverage ratios will have a detrimental impact on profitability. They said that when businesses buy a lot of assets, they must take on a lot of debt at a high cost. As a result, if a company's debt is bigger, it has a major impact on the company's performance. Taslim (2017) investigated the performance of Malaysian companies and found similar results to Ahmad (2017), who investigated the performance of Thai companies. Both studies demonstrated a negative interaction between debt ratios and company performance. They claimed that the less leverage a company uses, the more profit it may make, implying that the organisation is performing efficiently.

In Malaysia, Mokhtar et al (2006) studied at the elements that influence business performance. According to the findings, there is a significant positive relation between total asset and company performance, meaning that the larger the company, the more profit it generates, and hence the greater the company's performance. Furthermore, Ting et al. (2014) propose that the size of a corporation has a beneficial impact on its performance. Bashir et al. (2013) investigated the elements that have a substantial impact on the success of Pakistani food companies. Their findings from panel data revealed a positive relationship between total asset and company performance, implying that larger firms had more ability to boost production and more resources to improve sales, resulting in higher performance. The results were in accordance with those found by Bhutta and Hasan (2013) in their multivariate regression. Umi and Noraina (2017) found a significant positive relationship between total asset and company performance. This is because larger businesses are more likely to be diversified and have more predictable cash flows, therefore they have a lower risk of bankruptcy than smaller businesses. It is also confirmed by Alarussi and Alhaderi (2017), who led to the same conclusion, suggesting that when a firm grows in size, it becomes easier for it to access more financial resources, resulting in lower capital costs and more profits.

A tax rate is a percentage that a firm has charged to an individual or consumer who has purchased goods and services. The overwhelming of earlier research indicated a beneficial 
relationship between taxation and performance. According to Bashir et al (2013), who analysed the performance of Pakistan's food and beverage sector, when corporations charge taxes to individuals or consumers, it benefits to and helps the company's earnings grow. When a company's revenues increase, it suggests that the company's performance will improve as well. Phan (2013) had to agree with Bashir et al when his findings also shown a significant positive correlation between tax rate and the performance of the company in Thailand. owever, Ismail and Subramaniam (2017) found no significant positive correlation between tax rate and consumer product performance in Malaysia from 2006 to 2015. They also suggested that the tax rate and return on assets have a negative relationship. This is because financial performance can be explained by the way that more productive and profitable organisations record lower tax rates, a likely reason for these organisations' performance by management, as well as the advantage of current tax incentives.

Tangibility can be determined as the asset that can be touched and seen. The asset contains high value and will be the indicator for the company's earnings. The asset of the company is an essential for the company to utilize in order to gain a benefit and profit from it. Eitokpa (2015) investigated the factors that determine food and beverage financial performance in Nigeria. The studies revealed that asset tangibility is positively associated to the company's performance. It's similar to Bashir et al. (2013), who discovered that asset tangibility has a significant impact on return on asset (ROA), implying that more tangible food companies perform well. Ahmad (2017) examined at the performance of food and beverage companies in Malaysia and Thailand from 2004 to 2013 and reported that tax had no effect on performance, but the magnitude showed a significant association.

\section{Model Estimation}

Data for 133 companies that categorized under food and beverages sector that listed on Bursa Malaysia were gathered for ten years starting year 2008 until 2017. All data are retrieved from Thomsons Eikon Reuter's database. The significant variables affecting performance were determined using panel data and the Random Effect Model. Not only that, this method also used in order to observe the correspondence relationship between dependent and independent variables in this study. All analysis is done using Stata 10 package.

The general form of the Model Estimation:

$(R O A)_{i, t}=\beta_{0}+\beta_{1}(Q R)_{i, t}-\beta_{2}(D R)_{i, t}+\beta_{3}(T A)_{i, t}+\beta_{4}(T R)_{i, t}+\beta_{5}(T N)_{i, t}+\varepsilon_{i, t}$

Where:

$\begin{array}{ll}\text { ROA } & =\text { Return on Asset } \\ \text { QR } & =\text { Quick Ratio } \\ \text { DR } & =\text { Debt Ratio } \\ \text { TA } & =\text { Total Asset } \\ \text { TR } & =\text { Tax Rate } \\ \text { TN } & =\text { Tangibility } \\ \beta_{0} & =\text { Constant term } \\ \varepsilon_{i, t} & \text { = Error term }\end{array}$


In modelling performance decision, the return on asset is used as a dependent variable. The independent variables employed are quick ratio, debt ratio, total asset, tax rate and tangibility.

\section{Results and Analysis}

Table 1.1: Descriptive statistic of Shariah Compliance Firms

\begin{tabular}{lllllll}
\hline & ROA & QR & DR & TA & TR & TN \\
\hline Mean & 6.112 & 2.316185 & 38.08193 & 1102.124 & 22.09704 & 41.66226 \\
Maximum & 221.81 & 68.94 & 251.38 & 22939.63 & 850.7 & 91.19 \\
Minimum & -104.45 & 0.04 & 0.28 & 8.2314 & -179.20 & 5.99 \\
Std. Dev. & 3.137056 & 2.027543 & 0.7379989 & 3.078551 & 2.853814 & 0.4283432 \\
Observations & 270 & 270 & 270 & 270 & 270 & 270 \\
\hline
\end{tabular}

Table 1.2: Descriptive statistic of Non-Shariah Compliance Firms

\begin{tabular}{lllllll}
\hline & ROA & QR & DR & TA & TR & TN \\
\hline Mean & 9.045625 & 5.355375 & 43.09675 & 553.3843 & 26.1775 & 32.38675 \\
Maximum & 59.44 & 65.85 & 196.67 & 2059.399 & 176.6 & 81.59 \\
Minimum & -61.28 & 0.4 & 3.26 & 3.1298 & -13.5 & 3.16 \\
Std. Dev. & 2.223031 & 2.040589 & 0.6014866 & 0.7754828 & 1.020875 & 0.6668513 \\
Observations & 80 & 80 & 80 & 80 & 80 & 80 \\
\hline
\end{tabular}

Tables 1.1 and 1.2 show descriptive statistics for Shariah-compliance and non-compliance F\&B firms. Return on asset is the dependent variable in both categories. According to the tables, Shariah Compliance firm contributes a greater value for ROA, which hold at 221.81 percent, compared to Non-Shariah Compliance enterprises, which have a maximum profitability of just 59.44 percent ROA. However, Shariah Compliance firm has the lowest value of return on asset, which is -104.45 percent, while Non-Shariah Compliance firm has a significantly higher minimum value, which is just -61.28 percent. The first independent variable is the quick ratio, which shows the mean of Shariah Compliance firms' liquidity is 2.316 times, whereas the mean of Non-Shariah Compliance firms' liquidity is 5.355 times.

Shariah Compliance firm has the highest quick ratio value of 68.94 times, however there is a minor difference between Non-Shariah Compliance firm, which has a maximum value of 65.85 times. Shariah Compliance firm has a mean of 38.08193 percent debt ratio, whereas Non Shariah Compliance firm has a mean of 43.09675 percent, indicating a higher leverage. Apart from that, Shariah Compliance's total assets are RM 22939.63 million, whereas NonShariah Compliance's are RM 2059.399 million. Non-Shariah Compliance has the lowest total asset worth of RM 3.129 million, compared to RM 8.2314 million for Shariah compliance. 
Table 2.1: Correlation result of Shariah Compliance

\begin{tabular}{llr}
\hline Variables & Result \\
\hline 1. & Quick ratio & 0.2138 \\
2. Debt ratio & & -0.4325 \\
3. & Total asset & 0.2939 \\
4. Tax rate & & 0.0135 \\
5. & Tangibility & -0.2767 \\
\hline
\end{tabular}

Table 2.2: Correlation result of Non Shariah Compliance

\begin{tabular}{llr}
\hline Variables & Result \\
\hline 1. & Quick ratio & -0.1869 \\
2. Debt ratio & & -0.2219 \\
3. & Log asset & 0.2338 \\
4. & Tax rate & \\
5. & Tangibility & -0.1515 \\
\hline
\end{tabular}

Correlation analysis is tested to identify the association between variables which is dependent variables and independent variables. Based on table 2.1, it indicated a positive connection between quick ratios, log asset and tax rate with the dependent variable for Shariah Compliance firms. While for the Non-Shariah Compliance firms it showed that variables of debt ratios and tangibility are negatively correlated with return on assets.

Table 3.1: Pooled Ordinary Least Square (POLS) result of Shariah Compliance

\begin{tabular}{lccl}
\hline & Variables & Coef & $\mathbf{P}>\mathbf{~ I ~ t ~ I ~}$ \\
\hline $\mathbf{1}$ & Quick ratio & 0.6045828 & 0.007 \\
$\mathbf{2}$ & Debt ratio & -0.2362873 & 0.000 \\
$\mathbf{3}$ & Log asset & 1.632711 & 0.054 \\
$\mathbf{4}$ & Tax rate & -0.216642 & 0.198 \\
$\mathbf{5}$ & Tangibility & -0.1716995 & 0.009 \\
\hline
\end{tabular}

$* R^{2}=0.2590 \quad$ f-stat $=0.0000$

Table 3.2: Pooled Ordinary Least Square (POLS) result of Non Shariah Compliance

\begin{tabular}{llll}
\hline & Variables & Coef & P > I t I \\
\hline $\mathbf{1}$ & Quick ratio & -0.4177891 & 0.102 \\
$\mathbf{2}$ & Debt ratio & -0.3182546 & 0.002 \\
$\mathbf{3}$ & Total asset & 2.762105 & 0.227 \\
$\mathbf{4}$ & Tax rate & -0.222475 & 0.036 \\
$\mathbf{5}$ & Tangibility & -0.2449911 & 0.023 \\
\hline
\end{tabular}

$* R^{2}=0.2278 \quad$ f-stat $=0.0015$

A multiple regression of Pooled Ordinary Least Square findings is shown in Table 3.1. The results for Shariah Compliance show that the quick ratio, debt ratio, and tangibility are significant at 1 percent, and log asset is significant at 5 percent, affecting the return on asset, however the tax rate is not significant at any level. Furthermore, the quick ratio and log asset have demonstrated a positive link with return on asset, whereas other independent factors have showed a negative association. Table 3.2 presents the results for Non-Shariah Compliance, showing that the debt ratio, tax rate, and tangibility are significant at 1 and 5 percent, respectively, while the quick ratio and log asset are insignificant at any level in terms 
of return on asset, a contradictory result occurs. Secondly, only log asset has a positive connection with return on asset, while the remaining independent variables have a negative connection with return on asset.

Table 4.1: Result of Breusch Pagan Test of Shariah Compliance

$$
\text { Prob > chi2 }
$$

Table 4.2: Result of Breusch Pagan Test of Non Shariah Compliance

$$
\text { Prob > chi2 }
$$

To assess whether to pool or not to pool, the Breusch Pagan test is used. According to both tables above, the Shariah and Non-Shariah Compliance results are significant, with a chi square probability of less than 0.05 . In this investigation, the Random Effect Model (REM) will be applied.

Table 5.1: Random Effect Model (REM) result of Shariah Compliance

\begin{tabular}{lrrr}
\hline \multicolumn{2}{l}{ Variables } & Coef & P > I z I \\
\hline 1. & Quick ratio & 0.453244 & 0.032 \\
2. Debt ratio & -0.304025 & 0.000 \\
3. Log asset & 0.5293403 & 0.674 \\
4. Tax rate & -0.0368084 & 0.016 \\
5. & Tangibility & -0.2441286 & 0.005 \\
\hline $\mathrm{R}^{2}=0.2495 \quad$ prob F $>0.0000$ & &
\end{tabular}

\begin{tabular}{|c|c|c|c|}
\hline & Variables & Coef & $P>|z|$ \\
\hline & Quick ratio & -0.3962294 & 0.107 \\
\hline & Debt ratio & -0.2846214 & 0.010 \\
\hline 3. & Log asset & 3.835683 & 0.192 \\
\hline 4. & Tax rate & -0.2358968 & 0.013 \\
\hline 5. & Tangibility & -0.3794438 & 0.004 \\
\hline
\end{tabular}

Table 5.2: Random Effect Model (REM) result of Non Shariah Compliance

Random Effect regression for Shariah compliance firms found that, with the exception of log asset, all independent variables are significant in terms of return on asset, as shown in table 5.1. In addition, this result shows the relationship between quick ratio and log asset and profitability, with quick ratio and log asset having a positive relationship with profitability and debt ratio, tax rate, and tangibility having a negative link with profitability. The results for Non Shariah Compliance, on the other hand, show that debt ratio, tax rate, and tangibility are significant in impacting return on assets, whereas quick ratio and log asset are insignificant. It's also been discovered that for non-Shariah compliance, all independent factors are negatively correlated to return on assets, except for log asset, which has a positive link with profitability.

It suggests that quick ratios and return on assets have a positive association, based on the findings. Aside from that, this finding is similar to (Eitokpa, 2015; Dogan, 2013; Taslim, 2017). It is stated that if current assets are increased rather than current liabilities, the level of liquidity of the asset will improve, resulting in great performance of each company in the food 
and beverage sector. Non-Shariah Compliance, on the other hand, shows a different finding, indicating that the connection between quick ratios and return on assets is observed to be negative. According to the existing literature, an argument exists between quick ratios and return on assets, stating that the relationship between quick ratios and return on assets may be negatively associated. This finding is in line with the findings of Dioha et al (2018), Phan (2013); Ahmad (2017), indicating that enterprises with a larger liquidity ratio perform better than others since they have more financial resources. As a result, the corporation will be able to conduct normal business, resulting in improved performance.

The debt ratio, whether for Shariah or non-Shariah compliance enterprises, is becoming a significant determinant in the F\&B sector's profitability. Leverage and performance were found to have a negative relationship in both regressions. This finding is consistent with Taslim (2017); Umi and Noraina (2017), who found that the less leverage a company has, the more profit it may make, implying efficient firm performance.

Both Shariah and non-Shariah compliance indicated a negative significant relationship between tax rate and return on asset for the tax rate variable. The negative correlation between tax rate and return on assets is a probable outcome because in comparison to nonShariah compliance, most businesses will pay zakat and a lower tax rate. The burden on the customer will be increased if the tax rate is high. As a result, Shariah Compliance companies included zakat in their financial statements. This finding is consistent with Rashid et al (2017), who found that the corporate tax system induced 11.9 percent of the 59 companies in the final sample to participate in aggressive tax planning as they reported and declared zakat in their financial statements. This shown that when a corporation pays a higher amount of zakat, the company's performance suffers as a result of the outflow of funds. Non-Shariah Compliance, on the other hand, will see lower performance due to greater tax charges incurred by the business. This finding is consistent with Ismail and Subramaniam (2017), who found that more productive and profitable organisations had lower tax rates, which could be due to the fact that these organisations are more productive due to existing tax incentives. For both Shariah Compliance and Non-Shariah Compliance enterprises, tangibility is determined to be a significant element in impacting F\&B performance. Both regression analyses revealed a negative coefficient, implying that tangibility and profitability have a negative connection. This finding is identical to that of Bhutta and Hasan (2017), who found that firms with lower tangibility of assets are more productive. Ahmad (2017) agreed with this remark when he stated that the correlation is negative because the larger asset tangibility that companies own will lead the company's performance to be low or drop. This is due to the fact that increasing asset tangibility will increase the company's debt. When the company's debt grows, it will create an asset tangibility, which uses the company's fixed assets as collateral to repay the loans.

For both F\&B Shariah and Non-Shariah Compliance companies, the log asset, which indicated firm size, was shown to be insignificant at any level. Despite the fact that this variable has no effect on F\&B firm performance, the positive coefficient suggests that there is still a clear relationship between company size and performance. This is a comparable outcome to Mokhtar et al (2006), Ting et al (2014); Alarussi and Alhaderi (2017), suggested as a company grows in size, it becomes easier to access more financial resources, resulting in a reduced cost of capital and a higher profit. Umi and Noraina (2017) concurred with these findings, adding that because larger organisations are more diversified and have more consistent cash flows, the risk of bankruptcy is lower for them than for smaller enterprises. 


\section{Conclusion}

Based on the results of the previous chapter's analysis, it was discovered that Shariah Compliance has a greater performance than Non Shariah Compliance. The superior performance between Shariah and Non Shariah Compliance was owned by Shariah Compliance, which is 27.81 percent, as compared to Non Shariah Compliance, which is 26.03 percent, according to the trends of return on asset (ROA) between 2008 and 2017. Aside from that, the level of percentage of return on assets demonstrates that Shariah Compliance has a greater percentage in the food and beverage business than in the non-Shariah Compliance sector. This is in line with the Department of Statistics' (2015) assertion that companies in the Shariah Compliance category benefit the most. Except for total assets, the results of random effect model regression demonstrated that all independent factors, including quick ratio, debt ratio, tax rate, and tangibility, have a substantial impact on the ROA of Shariah compliance enterprises. Nonetheless, there are three independent variables that are significant for Non Shariah Compliance in terms of return on asset: debt ratio, tax rate, and tangibility. The profitability of non-Shariah compliant enterprises is unaffected by log assets or the quick ratio.

\section{References}

Ahmad, W. (2017). Pecking order theory: evidence from Malaysia and Thailand food and beverages industry. Jurnal Intelek, 12(1), 85-91.

Alarussi, A. S., \& Alhaderi, S. M. (2018). Factors affecting profitability in Malaysia. Journal of Economic Studies, 45(3), 442-458. https://doi.org/10.1108/JES-05-2017-0124

Bashir, Z., Abbas, A., Manzoor, S., \& Akram, M. N. (2013). Empirical investigation of the factors affecting firm's performance: A study based on food sector of Pakistan. International SAMANM Journal of Finance and Accounting, 1(2), 11-23.

Bhutta, N. T., \& Hasan, A. (2013). Impact of firm specific factors on profitability of firms in food sector.

Cheng, Y., \& Huang, Y. (2017). Determinants of Bank Profitability: Evidence From US.

Dioha, C., Mohammed, N. A., \& Okpanachi, J. (2018). Effect of firm characteristics on profitability of listed consumer goods companies in Nigeria.

Doğan, M. (2013). Does firm size affect the firm profitability? Evidence from Turkey. Research Journal of Finance and Accounting, 4(4), 53-59.

Eitokpa, O. H. (2015). Determinants of financial performance of listed foods and beverages companies in Nigeria (Doctoral dissertation, Doctoral Dissertation).

Ismail, N., \& Subramaniam, A. (2017). Factors affecting performance of consumer products companies in Malaysia. Journal of Global Business and Social Entrepreneurship (GBSE), 3(8).

Kraidi, A. A. (2015). A Comparative Study of Profitability Indicators of Commercial Banks in Turkey and the UAE. August.

Lusyana, D., and Sherif, M. (2017). Shariahcompliant investments and stock returns: evidence from the Indonesian stock market. Journal of Islamic Accounting and Business Research, $8(2), 143-160$

McGowan, Jr., C. B., \& Muhammad, J. (2010). The Theoretical Impact Of The Listing Of SyariahApproved Stocks On Stock Price And Trading Volume. International Business \& Economics Research Journal (IBER), 9(3), 11-20. https://doi.org/10.19030/iber.v9i3.532 
Yusoff, M. H. (2017). The effect of liquidity and solvency on profitability: the case of publiclisted consumer product companies in Malaysia (Doctoral dissertation, Universiti Tun Hussein Onn Malaysia).

Mokhtar, M. Z. (2006). An Evaluation of the factors affecting corporate performance of Malaysia listed companies. PhD Thesis, Dept. of Accounting and Finance, 44(0), 6.

Phan, K. C. (2013, December). Factors affecting profitability (Case of consumer products companies of Thailand). In International Conference on Innovations in Engineering and Technology (Vol. 25, No. 26, pp. 163-166).

Rashid, N., Ismail, W. N. S. W., Abd Rahman, M. S., \& Afthanorhan, A. (2018). Conceptual Analysis on Performance Measurement Used in SMEs Research: The Effectiveness of Firm's Overall Performance. International Journal of Academic Research in Business and Social Sciences, 8(11), 1401-1412.

Raza, A., Ansari, R. H., \& Younis, M. U. (2012). Does the loan loss provision profitability in case of Pakistan ? Asian Economic and Financial Review, 2(7), 772-783.

Sathyamoorthi, C. R., Christian, J. M., Mogotsinyana, M., \& Selinkie, P. (2018). The Impact of Corporate Governance on Working Capital Management Efficiency: Evidence from the Listed Companies in the Consumer Services Sector in Botswana. International Journal of Economics and Finance, 10(12), 135-149.

Shahar, W. S. S. B., \& Shahar, W. S. S. B. (2015, May). Impact of firm leverage to performance: evidence from Shariah and non-Shariah compliant companies in Malaysia. In International Conference on Economics and Banking (iceb-15). Atlantis Press.

Tailab, M. (2014). The effect of capital structure on profitability of energy American firms. International Journal of Business and Management Invention, 3(12).

Taslim, M. (2017). To Determinants Of A Firm's Profitability In Food And Beverage Industry: An Empirical Analysis On Oriental Food Industry Holding Berhad.

Ting, I. W. K., Kweh, Q. L., \& Chan, Y. C. (2014). Does organizational growth contribute to profitability? Evidence from Malaysian public listed companies. International Journal of Business and Society, 15(2), 267-276.

Umi, S. Z., Noraina, M. (2017). The Determinants of Firms Profitability in Consumer Product Sector. The European Proceedings of Social \& Behaviours Science, 661-669. 